\title{
Bone turnover markers in sheep and goat: A review of the scientific literature
}

\author{
JOSÉ A. CAMASSA ${ }^{1}$, CAMILA C. DIOGO ${ }^{1}$, CRISTINA P. SOUSA ${ }^{2}$, JORGE T. AZEVEDO ${ }^{3,4}$, \\ CARLOS A. VIEGAS ${ }^{1,5}$, RUI L. REIS ${ }^{6,7}$, NUNO DOURADO ${ }^{8}$ and ISABEL R. DIAS ${ }^{1,5}$ \\ ${ }^{1}$ Department of Veterinary Sciences, Agricultural and Veterinary Sciences School/ ECAV, University of \\ Trás-os-Montes and Alto Douro/ UTAD, Quinta de Prados, 5000-801 Vila Real, Portugal \\ ${ }^{2}$ Center Hospitalar of Porto, Largo Prof. Abel Salazar, 4099-001 Porto, Portugal \\ ${ }^{3}$ Department of Animal Sciences/ ECAV, UTAD, Quinta de Prados, 5000-801 Vila Real, Portugal \\ ${ }^{4}$ Centre for Animal Sciences and Veterinary Studies/ CECAV, UTAD, Quinta de Prados, 5000-801 Vila Real, Portugal \\ ${ }^{5}$ Centre for the Research and Technology of Agro-Environmental and Biological Sciences/ \\ CITAB, UTAD, Quinta de Prados, 5000-801 Vila Real, Portugal \\ 63B's Research Group - Biomaterials, Biodegradables and Biomimetics, Department of Polymer Engineering, University \\ of Minho, Avepark - Parque de Ciência e Tecnologia, Zona Industrial da Gandra, 4805-017 Barco GMR, Portugal \\ ${ }^{7}$ Life and Health Sciences Research Institute/ ICVS, School of Health Sciences, \\ University of Minho Campus de Gualtar 4710-057 Braga, Portugal \\ ${ }^{8}$ Department of Mechanical Engineering, University of Minho, Azurém Campus, 4804-533 Guimarães, Portugal
}

Manuscript received on June 25, 2016; accepted for publication on October 11, 2016

\begin{abstract}
Bone turnover markers (BTMs) are product of bone cell activity and are generally divided in bone formation and bone resorption markers. The purpose of this review was to structure the available information on the use of BTMs in studies on small ruminants, especially for monitoring their variations related to diet, exercise, gestation and metabolic lactation state, circadian and seasonal variations, and also during skeletal growth. Pre-clinical and translational studies using BTMs with sheep and goats as animal models in orthopaedic research studies to help in the evaluation of the fracture healing process and osteoporosis research are also described in this review. The available information from the reviewed studies was systematically organized in order to highlight the most promising BTMs in small ruminant research, as well as provide a wide view of the use of sheep and goat as animal models in orthopaedic research, type of markers and commercial assay kits with cross-reactivity in sheep and goat, method of sample and storage of serum and urine for bone turnover markers determination and the usefulness and limitations of bone turnover markers in the different studies, therefore an effective tool for researchers that seek answers to different questions while using BTMs in small ruminants.
\end{abstract}

Key words: Bone formation markers, bone resorption markers, bone metabolism, small ruminants.

\section{INTRODUCTION}

In the last decades, small ruminants - sheep and goats - have been widely accepted as animal mod-

Correspondence to: Isabel R. Dias

E-mail: idias@utad.pt els in orthopaedic research (O'Loughlin et al. 2008, Reichert et al. 2009) especially due to their low cost, availability, acceptance as an experimental model, facility of handling and housing (Turner 2007a), compliance, and docility (Newman et al. 1995). 
The suitability of small ruminants as animal models for orthopaedic research results mainly from having the most similar body weight and long bones with dimensions compatible with application of implants and prostheses developed for humans (Newman et al. 1995, Anderson et al. 1999, van der Donk et al. 2001). In this manner, compared with other species used in orthopaedic research, sheep and goats have an adequate body weight and long bones, with a macrostructure more similar to humans (Newman et al. 1995), despite the bone microstructure of small ruminants being less similar to humans than other animal models such as dogs (Pearce et al. 2007). Sheep have a predominance of plexiform bone until 3 to 4 years of age (Newman et al. 1995) due to fast growth in weight and size (Reinwald and Burr 2011) and just a predominance of secondary Haversian systems after 7 to 9 years of age with the presence of bone remodelling (Newman et al. 1995). Sheep also presents a trabecular bone density, mineralization and subsequently elevated strength relative to humans, that are variable according to skeletal location (Nafei et al. 2000, Liebschner 2004), nevertheless the bone mineral composition being apparently similar between small ruminants and humans (Ravaglioli et al. 1996).

Despite these macro- and micro-structural differences in bone tissue, studies with small ruminants used as animal models in orthopaedic research have increased considerably (Pearce et al. 2007), and more recently they have also been used for studying bone turnover markers (BTMs) (Sousa et al. 2014a). The BTMs are proteins which indicate bone metabolism (Sousa et al. 2014b), and are generally divided into collagenous bone formation markers, bone resorption markers and osteoclast regulatory protein markers (Leeming et al. 2006). Analysis of BTMs might supply information in a fast, effective, sensitive, specific, and low cost manner (Allen 2003). Nowadays, it is used in human medicine to help evaluate fracture risk, delayed fracture healing and consolidation process, and development of metabolic bone diseases (Vasikaran et al. 2011).

These similarities in biochemistry, biomechanics, and bone histology make BTMs a resource in sheep and goats for pre-clinical and/or translational orthopaedic research studies and veterinary and animal science studies (Turner 2007b). Nevertheless, the reported biological variability of BTMs among age, gender, disease, recent fractures, exercise, time (Seibel 2005), diet (Nicodemo et al. 1999, Liesegang and Risteli 2005, Liesegang et al. 2013), seasonal changes (Arens et al. 2007) and circadian variation (Liesegang et al. 2003), which can contribute substantially to the variability of these parameters (Smith et al. 2011), are their main limitation (Cremers et al. 2008).

Therefore, the aim of this review was to collect the studies published in scientific literature until the present date concerning the use of BTMs in small ruminant research or to investigate the clinical effectiveness of BTMs in pre-clinical or translational experimental orthopaedic research related to human medicine when sheep and goat are used as experimental animal models for this latter purpose.

\section{BONE TURNOVER MARKERS}

Bone tissue undergoes turnover along the animal lifespan (Seibel 2006) and that process is divided into two parts: modelling and remodelling (Clarke 2008).

Modelling is a longitudinal and circumferential growth process due to mechanical and/or physiological influences (Clarke 2008), with longitudinal growth located at the epiphyseal plates until their fusion uniting the epiphysis and metaphysis through endochondral ossification (Altman et al. 2015). It also allows the adaptation of bone tissue, removing damage and maintaining its strength (Seeman 2009), and requires that the process of bone formation and resorption are independent from one another regarding 
time and location (Raggatt and Partridge 2010). Remodelling is a process of bone replacement where bone formation outpaces bone resorption (Altman et al. 2015), to maintain bone strength and mineral homeostasis, regulated by osteoclasts and osteoblasts that sequentially carry out resorption of old bone and formation of new bone, keeping the new bone healthy (Clarke 2008). Bone remodelling predominates when bone is reaching maturity (Iglesias et al. 2011), but it does not influence the size and shape, although the internal architecture may have slight changes caused by external forces (Hadjidakis and Androulakis 2006). Bone formation and resorption are present in same site, but not at the same time in order to maintain bone mass (Raggatt and Partridge 2010).

The proteins produced during bone turnover are detectable mainly in serum in bone formation markers, whereas many of the bone resorption markers are detectable in both serum and urine (Allen 2003), and there are a significant number of commercial kits developed for use in humans that have cross-reactivity with other species, including sheep and goats (Tables I to III).

TABLE I

Bone formation markers, method of analysis and available commercial assay kits.

\begin{tabular}{|c|c|c|c|c|c|}
\hline Marker & Tissue of origin & Sample & $\begin{array}{l}\text { Method of } \\
\text { analysis }\end{array}$ & Available commercial Assay kit & $\begin{array}{l}\text { Cross-Reactivity } \\
\text { Sheep / Goat }\end{array}$ \\
\hline \multirow[t]{6}{*}{ BALP } & \multirow[t]{6}{*}{ Bone } & \multirow[t]{6}{*}{ Serum } & Colorimetric & No commercial kit available & $\mathrm{NO} / \mathrm{NO}$ \\
\hline & & & Electrophoretic & No commercial kit available & $\mathrm{NO} / \mathrm{NO}$ \\
\hline & & & Precipitation & No commercial kit available & $\mathrm{NO} / \mathrm{NO}$ \\
\hline & & & CLA & LIAISON BAP Ostase, Stillwater, MN, USA & $? / ?$ \\
\hline & & & ELISA & $\begin{array}{l}\text { MicroVue BAP, Quidel Corporation, San } \\
\text { Diego, CA, USA }\end{array}$ & YES / YES \\
\hline & & & RIA & $\begin{array}{l}\text { Tandem-R-Ostase, Beckman Coulter, Brea, } \\
\text { CA, USA }\end{array}$ & YES / ? \\
\hline \multirow[t]{6}{*}{$\mathrm{OC}$} & \multirow[t]{6}{*}{ Bone } & \multirow[t]{6}{*}{ Serum } & CLA & LIAISON Osteocalcin, Stillwater, MN, USA & $? / ?$ \\
\hline & & & RIA & $\begin{array}{l}\text { BTI Human Osteocalcin RIA, Biomedical } \\
\text { Technologies Inc, Stoughton, MA, USA }\end{array}$ & $? / ?$ \\
\hline & & & ELISA & $\begin{array}{l}\text { MicroVue Osteocalcin, Quidel Corporation, } \\
\text { San Diego, CA, USA }\end{array}$ & YES / YES \\
\hline & & & & $\begin{array}{l}\text { BTI Intact Osteocalcin, Biomedical } \\
\text { Technologies Inc, Stoughton, MA, USA }\end{array}$ & $? / ?$ \\
\hline & & & & $\begin{array}{l}\text { Osteocalcin, SIGMA, Saint Louis, Missouri, } \\
\text { USA }\end{array}$ & $? / ?$ \\
\hline & & & & $\begin{array}{l}\text { Osteocalcin, GenWay Biotech, San Diego, } \\
\text { CA, USA }\end{array}$ & $\mathrm{NO} / \mathrm{NO}$ \\
\hline \multirow[t]{3}{*}{ PINP } & \multirow[t]{3}{*}{ Bone, soft tissue } & \multirow[t]{2}{*}{ Serum } & CLA & PINP Roche Diagnostics, Penzberg, Germany & $? / ?$ \\
\hline & & & RIA & $\begin{array}{l}\text { UniQ Intact PINP, Orion Corporation, Espoo, } \\
\text { Finland }\end{array}$ & $? / ?$ \\
\hline & & Serum or urine & ELISA & PINP, Neobiolab Inc, Cambridge MA, UK & YES / YES \\
\hline \multirow[t]{4}{*}{ PICP } & \multirow[t]{4}{*}{ Bone, soft tissue } & \multirow[t]{3}{*}{ Serum } & RIA & PICP, Orion Corporation, Espoo, Finland & $? / ?$ \\
\hline & & & & PICP DiaSorin, Stillwater, MN, USA & YES / ? \\
\hline & & & ELISA & $\begin{array}{l}\text { MicroVue CICP, Quidel Corporation, San } \\
\text { Diego, CA, USA }\end{array}$ & YES / ? \\
\hline & & Serum or urine & & PICP, Neobiolab Inc, Cambridge MA, UK & YES / YES \\
\hline
\end{tabular}

BALP: Bone specific alkaline phosphatase; OC: Osteocalcin; PINP: Amino-terminal procollagen propeptides of collagen type I; PICP: Carboxy-terminal procollagen propeptides of collagen type I; RIA: Radioimmunoassay; ELISA: Enzyme-linked immunosorbant assay; CLA: Chemiluminescence immunoassay; YES: presence of cross-reactivity; NO: absence of crossreactivity; ?: no data available. 
TABLE II

Bone resorption markers, method of analysis and available commercial assay kits.

\begin{tabular}{|c|c|c|c|c|c|}
\hline Marker & $\begin{array}{c}\text { Tissue of } \\
\text { origin }\end{array}$ & Sample & $\begin{array}{c}\text { Method of } \\
\text { analysis }\end{array}$ & Available commercial Assay kit & $\begin{array}{c}\text { Cross-Reactivity } \\
\text { Sheep / Goat }\end{array}$ \\
\hline \multirow[t]{2}{*}{ HYP } & \multirow{2}{*}{$\begin{array}{l}\text { Bone, soft } \\
\text { tissue, cartilage }\end{array}$} & \multicolumn{2}{|c|}{ Serum or urine ELISA } & HYP, Neobiolab Inc, Cambridge MA, UK & YES / YES \\
\hline & & Urine & $\begin{array}{l}\text { Colorimetric } \\
\text { HPLC }\end{array}$ & No commercial kit available & $\mathrm{NO} / \mathrm{NO}$ \\
\hline \multirow[t]{4}{*}{ DPD } & \multirow[t]{4}{*}{ Bone, dentin } & \multirow[t]{2}{*}{ Urine } & ELISA & $\begin{array}{l}\text { MicroVue DPD, Quidel Corporation, San } \\
\text { Diego, CA, USA }\end{array}$ & YES / ? \\
\hline & & & HLPC & No commercial kit available & $\mathrm{NO} / \mathrm{NO}$ \\
\hline & & \multirow[t]{2}{*}{ Serum or urine } & ELISA & $\begin{array}{l}\text { MicroVue tDPD, Quidel Corporation, San } \\
\text { Diego, CA, USA }\end{array}$ & YES / ? \\
\hline & & & & DPD, Neobiolab Inc, Cambridge MA, UK & YES / YES \\
\hline \multirow[t]{4}{*}{ PYD } & \multirow{4}{*}{$\begin{array}{l}\text { Bone, cartilage, } \\
\text { blood vessels }\end{array}$} & Urine & HPLC & No commercial kit available & $\mathrm{NO} / \mathrm{NO}$ \\
\hline & & & ELISA & $\begin{array}{l}\text { MicroVue Serum PYD, Quidel Corporation, } \\
\text { San Diego, CA, USA }\end{array}$ & YES / ? \\
\hline & & & RIA & No commercial kit available & $\mathrm{NO} / \mathrm{NO}$ \\
\hline & & Serum or urine & ELISA & PYD, Neobiolab Inc, Cambridge MA, UK & YES / YES \\
\hline \multirow[t]{6}{*}{ ICTP } & \multirow[t]{6}{*}{ Bone, skin } & \multirow[t]{5}{*}{ Serum } & Colorimetric & No commercial kit available & $\mathrm{NO} / \mathrm{NO}$ \\
\hline & & & RIA & $\begin{array}{l}\text { ICTP, Incstar Corporation, Stillwatter, MN, } \\
\text { USA }\end{array}$ & $? / ?$ \\
\hline & & & & $\begin{array}{l}\text { UniQ ICTP, Orion Corporation, Espoo, } \\
\text { Finland }\end{array}$ & $? / ?$ \\
\hline & & & & ICTP DiaSorin, Stillwatter, MN, USA & $\mathrm{NO} / \mathrm{NO}$ \\
\hline & & & ELISA & $\begin{array}{l}\text { UniQ ICTP EIA, Orion Corporation, Espoo, } \\
\text { Finland }\end{array}$ & $? / ?$ \\
\hline & & \multicolumn{2}{|l|}{ Serum or urine } & ICTP, Neobiolab Inc, Cambridge MA, UK & YES / YES \\
\hline \multirow[t]{7}{*}{ CTx } & \multirow[t]{7}{*}{ Bone } & \multirow[t]{3}{*}{ Serum } & CLA & $\begin{array}{l}\beta \text {-Crosslaps Roche Diagnostics Penzberg, } \\
\text { Germany }\end{array}$ & $? / ?$ \\
\hline & & & RIA & No commercial kit available & $\mathrm{NO} / \mathrm{NO}$ \\
\hline & & & ELISA & $\begin{array}{l}\text { Serum CrossLaps, Biointernational, Yvette, } \\
\text { France }\end{array}$ & YES / ? \\
\hline & & \multirow[t]{3}{*}{ Urine } & CLA & $\begin{array}{l}\beta \text {-CrossLaps Roche Diagnostics Penzberg, } \\
\text { Germany }\end{array}$ & $? / ?$ \\
\hline & & & RIA & $\begin{array}{l}\text { CrossLaps RIA, Osteometer Biotech, Herlev, } \\
\text { Denmark }\end{array}$ & $? / ?$ \\
\hline & & & ELISA & $\begin{array}{l}\text { CrossLaps, Osteometer Biotech, Herlev, } \\
\text { Denmark }\end{array}$ & YES / YES \\
\hline & & Serum or urine & ELISA & CTx, Neobiolab Inc, Cambridge MA, UK & YES / YES \\
\hline \multirow[t]{5}{*}{ NTx } & \multirow[t]{5}{*}{ Bone } & \multirow[t]{3}{*}{ Serum } & RIA & No commercial kit available & $\mathrm{NO} / \mathrm{NO}$ \\
\hline & & & ELISA & $\begin{array}{l}\text { Osteomark Ostex International Inc., Seattle, } \\
\text { WA, USA }\end{array}$ & YES / ? \\
\hline & & & & NTx MyBioSourse, San Diego, CA, USA & \\
\hline & & Urine & RIA & No commercial kit available & $\mathrm{NO} / \mathrm{NO}$ \\
\hline & & Serum or urine & ELISA & NTx, Neobiolab Inc, Cambridge MA, UK & ? / YES \\
\hline Cathepsin $\mathrm{k}$ & Bone & Serum & ELISA & $\begin{array}{l}\text { Cathepsin k ELISA Kit, Antibodies-online, } \\
\text { Atlanta, Georgia, USA }\end{array}$ & $? / ?$ \\
\hline
\end{tabular}


TABLE II (continuation)

\begin{tabular}{|c|c|c|c|c|c|}
\hline Marker & $\begin{array}{c}\text { Tissue of } \\
\text { origin }\end{array}$ & Sample & $\begin{array}{l}\text { Method of } \\
\text { analysis }\end{array}$ & Available commercial Assay kit & $\begin{array}{l}\text { Cross-Reactivity } \\
\text { Sheep / Goat }\end{array}$ \\
\hline \multirow[t]{5}{*}{ TRAP } & \multirow[t]{5}{*}{ Bone } & \multirow[t]{4}{*}{ Serum } & RIA & No commercial kit available & $\mathrm{NO} / \mathrm{NO}$ \\
\hline & & & ELISA & $\begin{array}{l}\text { MicroVue TRAP 5b, Quidel Corporation, San } \\
\text { Diego, CA, USA }\end{array}$ & YES / YES \\
\hline & & & & $\begin{array}{l}\text { Osteolink-TRAP b, Nitto Boseki Corporation, } \\
\text { Tokio, Japan }\end{array}$ & $? / ?$ \\
\hline & & & & Bone TRAP SBA, Science, Boldon, UK & $? / ?$ \\
\hline & & Serum or urine & & TRAP, Neobiolab Inc, Cambridge MA, UK & YES / YES \\
\hline
\end{tabular}

HYP: Hydroxyproline; DPD: Deoxypyridinoline; PYD: Pyridinoline; ICTP: Carboxy-terminal telopeptide of type I collagen; CTx: cross-linked C-terminal telopeptides of type I collagen; NTx: cross- linked N-terminal telopeptides of type I collagen; TRAP 5b: Tartrate-resistant acid phosphatase isoenzyme 5b; RIA: Radioimmunoassay; ELISA: Enzyme-linked immunosorbant assay; CLA: Chemiluminescence immunoassay; HPLC: High-performance liquid chromatography.

\section{TABLE III}

Osteoclast regulatory proteins, method of analysis and available commercial assay kits.

\begin{tabular}{|c|c|c|c|c|c|}
\hline Marker & $\begin{array}{c}\text { Tissue of } \\
\text { origin }\end{array}$ & Sample & $\begin{array}{l}\text { Method of } \\
\text { analysis }\end{array}$ & Available commercial Assay kit & $\begin{array}{c}\text { Cross-Reactivity } \\
\text { Sheep / Goat }\end{array}$ \\
\hline \multirow[t]{3}{*}{ RANKL } & $\begin{array}{l}\text { Bone, } \\
\text { blood }\end{array}$ & Serum & ELISA & $\begin{array}{l}\text { Human Serum RANKL Free ELISA Kit, Biomedica } \\
\text { Medizinprodukte, GmbH \& Co. KG, Wien, Austria }\end{array}$ & $? / ?$ \\
\hline & & & & RANKL, Immundiagnostik AG, Bensheim, Germany & $? / ?$ \\
\hline & & Serum or urine & & RANKL, Neobiolab Inc, Cambridge MA, UK & YES / YES \\
\hline RANK & Bone & Serum & ELISA & RANK R\&D Systems, Minneapolis, MN, USA & $? / ?$ \\
\hline \multirow[t]{4}{*}{ OPG } & Bone & Serum & ELISA & $\begin{array}{l}\text { Human Osteoprotegerin ELISA kit, BioVendo } \\
\text { Laboratory Medicine, Inc., Labogen, Czech Republic }\end{array}$ & $\mathrm{NO} / \mathrm{NO}$ \\
\hline & & & & $\begin{array}{l}\text { Osteoprotegerin, Immundiagnostik AG, Bensheim, } \\
\text { Germany }\end{array}$ & $? / ?$ \\
\hline & & & & $\begin{array}{l}\text { Osteoprotegerin R\&D Systems, Minneapolis, MN, } \\
\text { USA }\end{array}$ & $? / ?$ \\
\hline & & Serum or urine & & OPG, Neobiolab Inc, Cambridge MA, UK & YES / YES \\
\hline
\end{tabular}

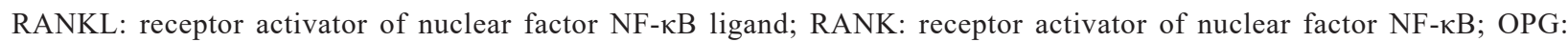
osteoprotegerin; ELISA: Enzyme-linked immunosorbant assay.

During the process of bone formation by osteoblasts, formation markers are represented by serum total (ALP) and the bone-specific isoform of alkaline phosphatase (BALP), serum osteocalcin (OC) and two molecules which are released during the type I collagen molecule synthesis - serum procollagen type I carboxy- and amino-terminal propeptides (PICP and PINP, respectively) (Seibel 2002). In the bone resorption process there is a breakdown of type I collagen, so resorption markers are represented by serum C-terminal telopeptide of type I collagen (serum ICTP), urinary collagen type I cross-linked C- and N-telopeptide (CTx and NTx), urinary hydroxyproline (HYP), total and free uri- nary pyridinoline and deoxypyridinoline (PYD and DPD) and also by serum tartrate-resistant acid phosphatase (TRAP) as an enzyme produced by osteoclasts during their bone resorption activity (Seibel 2002) (Figure 1).

\section{BONE FORMATION MARKERS}

\section{ALKALINE PHOSPHATASE}

Alkaline phosphatase (ALP) is a glycoprotein that is connected to the extracellular surface of cells and is synthesized in a variety of tissues, such as intestines, placenta, and germ cells (Millan 2006). Animals have four isoforms of ALP - bone-specific 


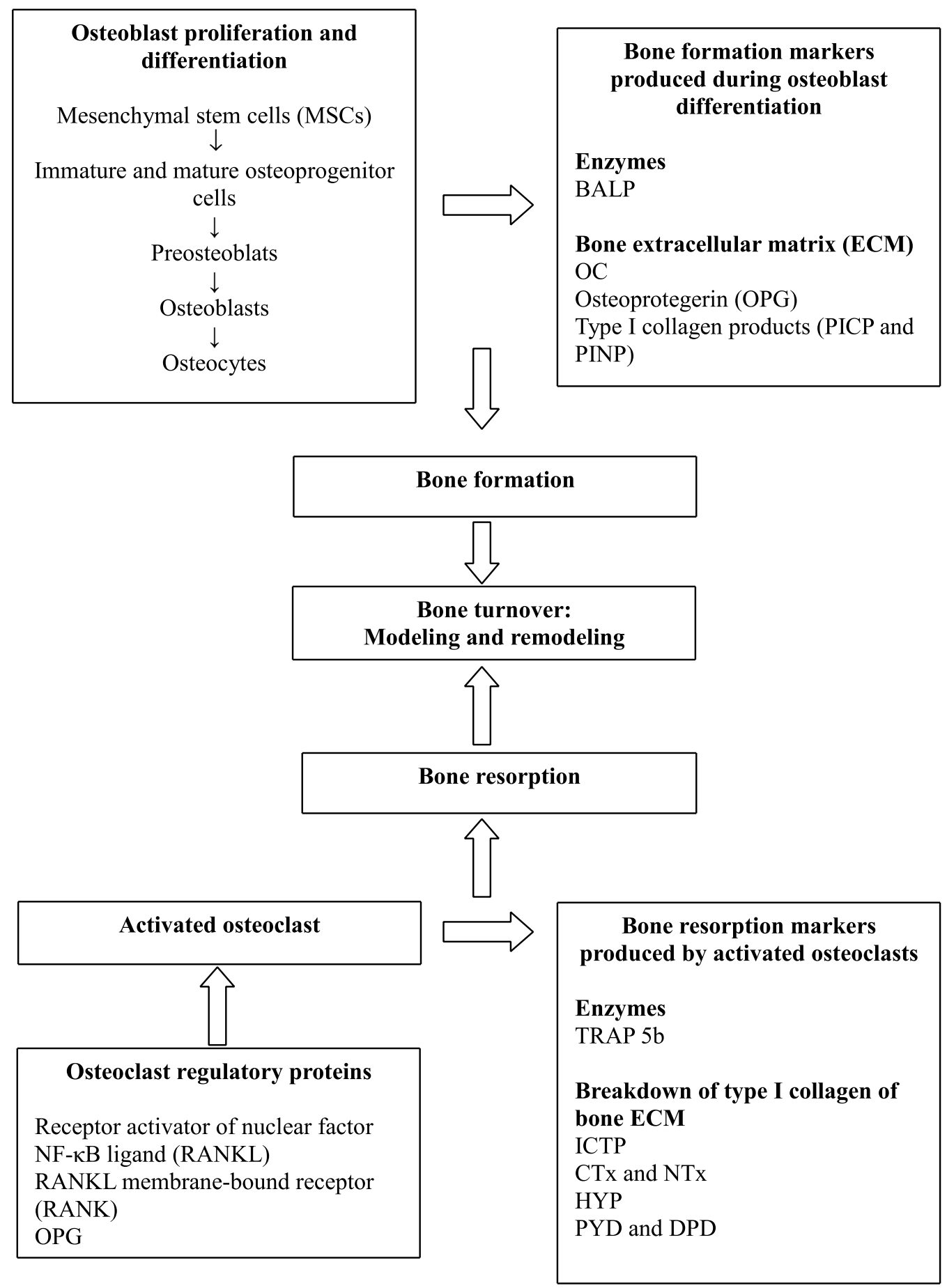

Figure 1 - Flow diagram of BTMs produced during the bone turnover process.

ALP (BALP), intestinal ALP, liver ALP, and in dogs also the corticosteroid-induced ALP. This variation would render difficult the interpretation of possible variations of the ALP isoenzymes
(Allen 2003). Bone ALP has been used due to its high sensitivity as bone formation marker (Seibel 2006). It is produced by osteoblasts (Millan 2006) and is involved in the calcification of bone 
matrix (Masrour and Mahjoub 2012) through the hydrolysis of phosphate esters on the osteoblast cell surface, resulting in a high extracellular inorganic phosphate concentration (Whyte 1994).

\section{OSTEOCALCIN}

Osteocalcin (OC) is synthesized by mature osteoblasts, odontoblasts, and hypertrophic chondrocytes and it is vitamin $\mathrm{K}$ dependent protein. It has three residues of the calcium-binding amino acid, $\gamma$ - carboxyglutamic acid (Gla). Its function is poorly understood, although it is primarily deposited in the bone extracellular matrix (ECM), with a small amount present in the blood stream (Cremers et al. 2008). Serum OC is a marker of osteoblastic activity and its serum level thus reflects the rate of bone formation (Seebeck et al. 2005), influences bone mineralization by binding calcium and consequently hydroxyapatite (Neve et al. 2013).

\section{PRO-COLLAGEN TYPE I PROPEPTIDES}

Collagen type I is produced by osteoblasts in the last stage of new bone formation (Allen 2003). The procollagen undergoes enzymatic cleavage producing the $\mathrm{C}$ - and $\mathrm{N}$-terminal procollagen type I extension peptides (PICP and PINP, respectively), both extension are cleared by the liver and may be added to the bone ECM (Watts 1999). Nevertheless, type I collagen does not depend exclusively on the bone tissue turnover because it is also a component of other soft tissues as fibro-cartilage, tendon, skin, gum, intestine, heart valve, large vessels, and muscle. However, as the metabolism of type I collagen is faster in the bone tissue than in other tissues, changes in type I collagen are considered representative of bone collagen synthesis (Cremers et al. 2008). It is suggested that PINP is useful in early detection of non union processes with potential for study of the fracture healing process (Coulibaly et al. 2010), although in humans it is unknown whether there exists a correspondence between PINP and the progression of fracture healing (Moghaddam et al. 2011).

\section{BONE RESORPTION MARKERS}

\section{DEOXYPYRIDINOLINE AND PYRIDINOLINE}

The collagen fibrils recently deposited in bone ECM are stabilized by intra- and intermolecular cross links helping to build the mature collagen molecule (Cepelak and Cvorišcec 2009).

The pyridinium cross links - deoxypyridinoline (DPD) and pyridinoline (PYD) are formed during extracellular maturation of fibrillar collagens (Gerrits et al. 1995). The PYD is found in bone and cartilage tissues and ligaments (Watts 1999) while DPD is found in bone and dentin (Delmas et al. 2000), so in the bloodstream PYD is generally more abundant (Cremers et al. 2008), although DPD is more specific as a resorption marker for bone tissue (Seibel et al. 1992). In a study with sheep after ovariectomy, this animal model demonstrated relevance as a model for osteoporosis due to the values of PYD and OC found (Newton et al. 2004).

\section{CARBOXY-TERMINAL TELOPEPTIDE OF COLLAGEN TYPE I AND AMINO-TERMINAL TELOPEPTIDE OF COLLAGEN TYPE I}

The N-terminal (NTx) and C-terminal telopeptide of collagen type I (CTx) are fragments of the type I collagen molecule composed by a short peptide sequence from the non-helical domain of this molecule (Chubb 2012), attached by a pyridinium crosslink (Allen et al. 2000). Both markers are sensitive and reliable indicators of the bone resorption process (Cremers et al. 2008) and final products of the metabolism of bone ECM, amino acids, and free or peptide-bound PYD or DPD (Allen et al. 2000).

The CTx is not specific as a resorption marker for bone tissue since it is identified not only in bone, but also in skin, dentine, and tendon, and these peptide fragments could also be derived from 
other types of collagen (Chubb 2012). However, CTx could be used for monitoring the bone healing process because it was detected that variations in its levels corresponded to bone resorption in an experimental fracture healing study performed in dogs where two different osteosynthesis techniques were used (Paskalev and Krastev 2010).

CARBOXY-TERMINAL TELOPEPTIDE OF TYPE I COLLAGEN - MATRIX METALLOPROTEINASE

Cleavage of the type I collagen molecule by the matrix metalloproteinases (MMP) results in the formation of cross-linked C-terminal telopeptide of type I collagen (CTX-MMP or ICTP) (Cremers et al. 2008), suitable to represent osteoclastic activity (Allen et al. 2000).

The ICTP is an indicator for mobilization of bone tissue around parturition and at the beginning of lactation in sheep and goats (Liesegang et al. 2007). In dogs with osteosarcoma (Hintermeister et al. 2008) and horses during physical training, this marker has not revealed itself suitable for determining bone resorption since it did not show correlation with other resorption markers, however it was an indicator of the rate of bone turnover (Price et al. 1995).

\section{TARTRATE-RESISTANT ACID PHOSPHATASE}

Tartrate-resistant acid phosphatase (TRAP) is a bone resorption marker, but not originated from the degradation of type I collagen (Hannon et al. 2004). It is a glycoprotein produced by osteoclasts, activated macrophages, and dendritic cells (Leeming et al. 2006). There is an isoenzyme 5, from a total of 6 isoenzymes of the acid phosphate identified by electrophoresis, which through protease cleavage presents two isoforms $(a, b)-$ the TRAP 5a is sialylated and TRAP 5b is produced by osteoclasts, and the latter proposed to reflect osteoclast activity (Delmas et al. 2000, Leeming et al. 2006). The TRAP could be a suitable resorption marker for detection of normal or delayed fracture healing process in sheep (Seebeck et al. 2005) or dogs (Sousa et al. 2011).

\section{CATHEPSIN K}

Cathepsin $\mathrm{K}$ is part of the cysteine protease family and has the ability to cleave both helical and telopeptide regions of collagen type I (Leeming et al. 2006). This enzymatic cleavage is able to degrade, at low $\mathrm{pH}$, several proteins of the bone ECM, namely the telopeptide and helical regions of the collagen type I molecule, the OC and osteopontin (Cremers et al. 2008). This marker could be used as a tool to measure bone resorption, such as in canine osteosarcoma clinical cases (Schmit et al. 2012).

\section{VARIABILITY OF BONE TURNOVER MARKERS}

The BTMs could suffer constant variation throughout the lifetime of an individual (Sousa et al. 2014b). However, variation between individuals is also a great cause of oscillation in markers, specifically due to biological variability, together with the analytical variability introduced by the different assay techniques (Vasikaran et al. 2011).

Biological variability can be influenced by many uncontrollable factors (Cremers et al. 2008), such as growth (Sousa et al. 2014a), geographical location (Liesegang et al. 2013), pregnancy and lactation (Liesegang et al. 2006, Liesegang et al. 2007), and controllable factors, such as diet (MacLeay et al. 2004a, b, Liesegang et al. 2013), and season of the year (Arens et al. 2007), which can be mitigated in clinical studies (Liesegang 2008). In short, biological variability is affected by any factor that influences the bone remodelling (Watts 1999).

Analytical variability has been minimized due to automated platform technology, however, there could be variations in results between different methods (Cremers et al. 2008) and the development of new analytical techniques requires previous validation (Seibel et al. 2001). 
The high inter-individual variability of BTMs is their main limitation for clinical use due to the difficulty to establish reference ranges for serum and urinary BTM levels (Souberbielle et al. 1999), although bone markers are an effective tool in clinical studies due to reliable, fast, non-invasive, and cost effective assays with improved sensitivity and specificity (Wheater et al. 2013).

\section{SAMPLE AND STORAGE}

Blood collection for measuring BTMs must be done at a specific time (morning) to avoid the influence of circadian variations (Klein et al. 2004, Seebeck et al. 2005, Dias et al. 2008, Sousa et al. 2014a, b). Blood samples can be collected from the cephalic vein (Klein et al. 2004) or jugular vein (Dias et al. 2008, Sousa et al. 2014a, b) into serological tubes containing no anticoagulant (Vernon et al. 2010), and centrifuged (3000 rpm for $10 \mathrm{~min}$ ) within 30 min of collection (Liesegang et al. 2007). Urine can be obtained using a special external urine collector (Windhagen et al. 2002) or collected by cystocentesis (Allen et al. 2000). Urine and serum samples should be stored at $-20^{\circ} \mathrm{C}$ for mineral analyses (Chanetsa et al. 2000, Taylor et al. 2009, Sousa et al. 2014a) and at $-80^{\circ} \mathrm{C}$ until determination of BTMs (Seebeck et al. 2005, Tatara 2008, Sousa et al. 2014b), which provides molecular stability for several months (Lomeo and Bolner 2000).

\section{ANIMAL AND VETERINARY SCIENCE STUDIES}

Characteristics of the animal and veterinary science studies regarding population, type of studies, time, and conclusion (Table SIV - Supplementary Material).

\section{DIET}

According to Liesegang and Risteli (2005) Liesegang et al. (2013), MacLeay et al. (2004a, b) and Nicodemo et al. (1999) nutritional studies using BTMs were influenced by different diets, though this influence was not statistically significant. MacLeay et al. (2004a) concluded that during the administration of a diet that induced metabolic acidosis in mature ewes, there were no significant changes in serum BALP and DPD levels. In another study by Liesegang et al. (2013) with sheep grazing at different altitudes, it was not possible to confirm the interference of diet in the serum variation of ICTP or BALP, but high bone turnover was confirmed. Also, in a study by Liesegang and Risteli (2005) where a diet with varying calcium content was used, it was not possible to demonstrate the influence of the diet on bone mineral metabolism in growing goats and sheep, possibly due to the short duration of this study, where only the sheep showed a variation in BMD due to an increase in calcium intake. However, Wilkens et al. (2010) demonstrated that sheep were a suitable model for studies with varying diets, calcium deficiency, and calcitrol.

\section{EXERCISE}

Liesegang and Risteli (2005) demonstrated that sheep in pasture at high altitudes had an increase in bone turnover and bone mineral content without clear cause, one possible factor being the increase in exercise. In another study in lambs, Vernon et al. (2010) concluded that the markers used were not adequate to indicate the effects of forced exercise.

\section{GESTATION AND LACTATION}

Liesegang et al. (2006) noticed that the interval between parturition and early lactation in sheep and goats required a high nutritional value of calcium due to losses to the fetus and lactation, occurring inefficiency of calcium absorption, leading to increases in bone remodelling to help replace maternal bone loss classified as a physiological mechanism. During a second pregnancy, bone loss was less significant compared with the first pregnancy and the lactation greater, possibly due 
to the adaptation of the organism (Liesegang et al. 2007). Finally, it was concluded that sheep were more adapted to the loss of calcium in comparison to goats, that had a lower bone mineral density and bone mineral content before parturition (Liesegang and Risteli 2005) increased bone turnover, resulting in a higher activity of bone metabolism and sensitivity to changes in calcium during pregnancy and lactation (Liesegang et al. 2003).

\section{CIRCADIAN AND SEASONAL VARIATION}

Chavassieux et al. (1991) reported that bone remodelling was influenced by the photoperiod, with decrease in bone remodelling occurring between spring and summer. Arens et al. (2007) confirmed that bone mass increases in summer and decreases in winter, so taking seasonal variation into account is fundamental in studies using BTMs. Liesegang et al. (2003) reported an increase in the rate of bone formation during the evening and night, indicating the influence of the circadian rhythm in bone turnover. Sousa et al. (2014b) concluded that the short-term variability should be considered during interpretation of data, such as circadian and seasonal variations, nevertheless the short-term biological variability do not represent a limitation for the use of BTMs.

\section{SKELETAL GROWING}

Pastoureau et al. (1991) mention that sheep are a good model to study the bone growth in growing lamb. It was reported that goats showed a more accelerated bone remodelling that sheep, which was demonstrated by ICTP, CTx (Liesegang et al. 2003), BALP (Liesegang et al. 2003, Sousa et al. 2014a), and OC determinations in various studies (Pastoureau et al. 1991, Liesegang et al. 2003). Collignon et al. (1996) demonstrated that bone growth since the fetal stage produces alterations in serum OC and BALP, confirming the usefulness of these markers in bone formation and growth. Scott et al. (1997) reported that OC, BALP, DPD, and PYD may be useful for detection of changes in bone growth caused by deficient diets, and Wan Zahari et al. (1994) reported that high phosphorus diets resulted in increased bone resorption (increased TRAP) in lambs. However, Chanetsa et al. (2000) exposed castrated lambs to an oestrogen agonist. In this study, bone growth was observed, but no effect on markers of bone remodelling was noticed.

\section{PRE-CLINICAL AND TRANSLATIONAL ORTHOPAEDIC RESEARCH STUDIES}

The characteristics of the pre-clinical and translational orthopaedic research studies, such as population, type of studies, time, and conclusion are listed in Table SIV.

\section{FRACTURE HEALING PROCESS}

Tralman et al. (2013) and Windhagen et al. (2002) reported that the serum markers of bone formation are useful for reflecting the bone healing process, and Goebel et al. (2009) suggested that FGF23 is a good marker to indicate the healing process. Seebeck et al. (2005) stated that degradation of soft callus can be determined by serum PIIINP during the bone fracture healing process and Schmidt et al. (2008) concluded that it is possible to monitor the maturation of bone callus with the total ALP and NTx. However, without individual reference values, BTMs become a weak tool to determine the prognosis of bone consolidation (Klein et al. 2004).

\section{OSTEOPOROSIS}

Newton et al. (2004) reported that ovariectomized (OVX) ewe were a useful model due to alterations in trabecular bone architecture along with the decrease in oestrogen levels, which resemble women in early menopause and Turner (2001) suggested that old OVX ewes could be a valid model for bone loss due to oestrogen deficiency. Johnson et al. (2002) reported that 6 months after 
OVX in sheep there was a decrease in alveolar bone BMD which became serious during the next 6 months. However, Sigrist et al. (2007) reported that in sheep, 6 months after the OVX, the markers for formation and resorption returned to baseline, indicating that the model was not appropriate for human postmenopausal osteoporosis. Kreipke et al. (2014) reported that OVX induces the necessary changes in bone microarchitecture for studying osteoporosis, but after a year, the changes in architecture stabilize in ovine. Chavassieux et al. (2001) reported that in goats, remodelling occurred only in the cortical bone tissue regions, which was also demonstrated by increased levels of CTx one month after OVX and OC three months after OVX.

Ding et al. (2010) and Andreasen et al. (2015) stated that the induction by glucocorticoids in sheep is similar to the change in the microstructure of human bone also induced by long-term glucocorticoid treatment, therefore being a useful model. MacLeay et al. (2004b) though not knowing what the true mechanism is involved in diets that induce metabolic acidosis in bone loss, concluded that the sheep model is useful for studies of osteoporosis induced by diet.

Therefore, small ruminant models are important for the study of human osteoporosis (Chavassieux et al. 1997, Lill et al. 2002a, b, Andreasen et al. 2015, Kielbowicz et al. 2015, 2016) induced by OVX and with attention to continuous treatment with glucocorticoids to maintain the osteoporotic bone condition (Ding et al. 2010).

\section{CONCLUSIONS}

The suitability of the determination of BTMs in small ruminants is already confirmed in numerous animal and veterinary sciences studies and also in preclinical and/or translational studies in orthopaedic research, in addition to imaging, mechanical, histological and histomorphometric analyses. Their advantage relies on a fast and non-invasive assessment via biochemical analysis of serum or urine samples, although the referred negative aspect of using BTMs in the clinical setting is related with their high biological variability. Particularly in sheep, BTMs have been used to estimate the extent of the osteogenic response at a local level at the fracture healing site, as precocious indicators of possible bone healing disturbances. BTMs could provide important information concerning bone metabolism at a systemic level, namely about bone remodelling process during induction of osteoporosis and its treatment in experimental orthopaedic studies. Recently it was developed a study by Baharuddin et al. (2014) in sheep with osteoclast regulatory protein receptor activator of nuclear factor NF- $\mathrm{B}$ ligand (RANKL) produced by osteocytes, osteoblasts and immune system cells, its membrane-bound receptor (RANK) in the osteoclast precursor cells and osteoprotegerin (OPG) as new potential bone markers in future (Sousa et al. 2015), nevertheless more studies would be necessary to assess the usefulness of BTMs in this scientific field.

\section{ACKNOWLEDGMENTS}

José Arthur de A. Camassa acknowledges to the Conselho Nacional de Desenvolvimento Científico e Tecnológico (CNPq), Brazil, for his $\mathrm{PhD}$ scholarship 202248/2015-1.

\section{REFERENCES}

ALLEN MJ. 2003. Biochemical markers of bone metabolism in animals: uses and limitations. Vet Clin Pathol 32: 101113.

ALLEN MJ, ALLEN LC, HOFFMANN WE, RICHARDSON DC AND BREUR GJ. 2000. Urinary markers of type I collagen degradation in the dog. Res Vet Sci 69: 123-127.

ALTMAN AR, TSENG WJ, DE BAKKER CM, CHANDRA A, LAN S, HUH BK, LUO S, LEONARD MB, QIN L AND LIU XS. 2015. Quantification of skeletal growth, modelling, and remodelling by in vivo micro computed tomography. Bone 81: 370-379.

ANDERSON ML, DHERT WJ, DE BRUIJN JD, DALMEIJER RA, LEENDERS H, VAN BLITTERSWIJK CA AND 
VERBOUT AJ. 1999. Critical size defect in the goat's os ilium. A model to evaluate bone grafts and substitutes. Clin Orthop Relat Res 364: 231-239.

ANDREASEN CM, DING M, OVERGAARD S, BOLLEN P AND ANDERSEN TL. 2015. A reversal phase arrest uncoupling the bone formation and resorption contributes to the bone loss in glucocorticoid treated ovariectomised aged sheep. Bone 75: 32-39.

ARENS D, SIGRIST I, ALINI M, SCHAWALDER P, SCHNEIDER E AND EGERMANN M. 2007. Seasonal changes in bone metabolism in sheep. Vet J 174: 585-591.

BAHARUDDIN NA, COATES DE, CULLINAN M, SEYMOUR G AND DUNCAN W. 2014. Localization of rank, rankl and osteoprotegerin during healing of surgically created periodontal defects in sheep. J Periodont Res 50: 211-219.

CEPELAK I AND CVORIŠCEC D. 2009. Biochemical markers of bone remodeling - review. Biochem Medica 19: 17-35.

CHANETSA F, HILLMAN LS, THOMAS MG AND KEISLER DH. 2000. Estrogen agonist (zeranol) treatment in a castrated male lamb model: effects on growth and bone mineral accretion. J Bone Miner Res 15: 1361-1367.

CHAVASSIEUX P, BUFFET A, VERGNAUD P, GARNERO P AND MEUNIER PJ. 1997. Short-term effects of corticosteroids on trabecular bone remodeling in old ewes. Bone 20: 451- 455.

CHAVASSIEUX P, GARNERO P, DUBOEUF F, VERGNAUD P, BRUNNER-FERBER F, DELMAS PD AND MEUNIER PJ. 2001. Effects of a new selective estrogen receptor modulator (MDL 103,323) on cancellous and cortical bone in ovariectomized ewes: a biochemical, histomorphometric, and densitometric study. J Bone Miner Res 16: 89-96.

CHAVASSIEUX P, PASTOUREAU P, BOIVIN G, DELMAS PD, CHAPUY MC AND MEUNIER PJ. 1991. Effects of ossein-hydroxyapatite compound on ewe bone remodelling: Biochemical and histomorphometric study. Clin Rheumatol 10: 269-273.

CHUBB SA. 2012. Measurement of C-terminal telopeptide of type I collagen (CTX) in serum. Clin Biochem 45: 928935.

CLARKE B. 2008. Normal bone anatomy and physiology. Clin J Am Soc Nephrol 3: 131-139.

COLLIGNON H, DAVICCO MJ AND BARLET JP. 1996. Metacarpal growth and systemic markers of bone metabolism in the ovine fetus. Reprod Fertil Dev 8: 287295.

COULIBALY MO, SIETSEMA DL, BURGERS TA, MASON J, WILLIAMS BO AND JONES CB. 2010. Recent advances in the use of serological bone formation markers to monitor callus development and fracture healing. Crit Rev Eukaryot Gene Expr 20: 105-127.
CREMERS S, GARNERO P AND SEIBEL MJ. 2008. Biochemical markers of bone metabolism. In: Bilezikian JP, Raisz LG and Martin TJ (Eds), Bone Biology, San Diego: Elsevier, San Diego, USA, p. 1857-1882.

DELMAS PD, EASTELL R, GARNERO P, SEIBEL MJ AND STEPAN J. 2000. The use of biochemical markers of bone turnover in osteoporosis. Committee of Scientific Advisors of the International Osteoporosis Foundation. Osteoporos Int 11: 2-17.

DIAS IR, VIEGAS CA, DE AZEVEDO JT, COSTA EM, LOURENCO P, RODRIGUES A AND CABRITA AS. 2008. Assessment of markers of bone formation under controlled environmental factors and their correlation with serum minerals in adult sheep as a model for orthopaedic research. Lab Anim 42: 465-472.

DING M, CHENG L, BOLLEN P, SCHWARZ P AND OVERGAARD S. 2010. Glucocorticoid induced osteopenia in cancellous bone of sheep: validation of large animal model for spine fusion and biomaterial research. Spine 35: 363-370.

GERRITS MI, THIJSSEN JH AND VAN RIJN HJ. 1995. Determination of pyridinoline and deoxypyridinoline in urine, with special attention to retaining their stability. Clin Chem 41: 571-574.

GOEBEL S, LIENAU J, RAMMOSER U, SEEFRIED L, WINTGENS KF, SEUFERT J, DUDA G, JAKOB F AND EBERT R. 2009. FGF23 is a putative marker for bone healing and regeneration. J Orthop Res 27: 1141-1146.

HADJIDAKIS DJ AND ANDROULAKIS II. 2006. Bone remodelling. Ann NY Acad Sci 1092: 385-396.

HANNON RA, CLOWES JA, EAGLETON AC, AL HA, EASTELL R AND BLUMSOHN A. 2004. Clinical performance of immunoreactive tartrate-resistant acid phosphatase isoform $5 \mathrm{~b}$ as a marker of bone resorption. Bone 34: 187-194.

HINTERMEISTER JG, JONES PD, HOFFMANN WE, SIEGEL AM, DERVISIS NG AND KITCHELL BE. 2008. Measurement of serum carboxyterminal cross-linked telopeptide of type I collagen concentration in dogs with osteosarcoma. Am J Vet Res 69: 1481-1486.

IGLESIAS L, YEH JK, CASTRO-MAGANA M AND ALOIA JF. 2011. Effects of growth hormone on bone modeling and remodeling in hypophysectomized young female rats: a bone histomorphometric study. J Bone Miner Metab 29: 159-167.

JOHNSON RB, GILBERT JA, COOPER RC, PARSELL DE, STEWART BA, DAI X, NICK TG, STRECKFUS CF, BUTLER RA AND BORING JG. 2002. Effect of estrogen deficiency on skeletal and alveolar bone density in sheep. J Periodontol 73: 383-391.

KIEŁBOWICZ Z，PIĄTEK A，BIEŻYŃSKI J, SKRZYPCZAK P, KUROPKA P, KURYSZKO J, NIKODEM A, KAFARSKI P AND PEZOWICZ C. 
2015. The experimental osteoporosis in sheep - Clinical approach. Pol J Vet Sci 3: 645-654.

KIEŁBOWICZ Z, PIĄTEK A, KUROPKA P, MYTNIK E, NIKODEM A, BIEŻYŃSKI J, SKRZYPCZAK P, PEZOWICZ C, KURYSZKO J AND REICHERT P. 2016. Experimental osteoporosis in sheep - Mechanical and histological approach. Pol J Vet Sci 19: 109-118.

KLEIN P, BAIL HJ, SCHELL H, MICHEL R, AMTHAUER H, BRAGULLA H AND DUDA GN. 2004. Are bone turnover markers capable of predicting callus consolidation during bone healing? Calcif Tissue Int 75: 40-49.

KREIPKE TC, RIVERA NC, GARRISON JG, EASLEY JT, TURNER AS AND NIEBUR GL. 2014. Alterations in trabecular bone microarchitecture in the ovine spine and distal femur following ovariectomy. J Biomech 47: 19181921.

LEEMING DJ, ALEXANDERSEN P, KARSDAL MA, QVIST P, SCHALLER S AND TANKO LB. 2006. An update on biomarkers of bone turnover and their utility in biomedical research and clinical practice. Eur J Clin Pharmacol 62: 781-792.

LIEBSCHNER MA. 2004. Biomechanical considerations of animal models used in tissue engineering of bone. Biomaterials 25: 1697-1714.

LIESEGANG A. 2008. Influence of anionic salts on bone metabolism in periparturient dairy goats and sheep. J Dairy Sci 91: 2449-2460.

LIESEGANG A, HUTTENMOSER D, RISTELI J, LEIBER F, KREUZER M AND WANNER M. 2013. Influence of high-altitude grazing on bone metabolism of growing sheep. J Anim Physiol Anim Nutr (Berl) 97: 58-66.

LIESEGANG A AND RISTELI J. 2005. Influence of different calcium concentrations in the diet on bone metabolism in growing dairy goats and sheep. J Anim Physiol Anim Nutr (Berl) 89: 113-119.

LIESEGANG A, RISTELI J AND WANNER M. 2006. The effects of first gestation and lactation on bone metabolism in dairy goats and milk sheep. Bone 38: 794-802.

LIESEGANG A, RISTELI J AND WANNER M. 2007. Bone metabolism of milk goats and sheep during second pregnancy and lactation in comparison to first lactation. $\mathrm{J}$ Anim Physiol Anim Nutr (Berl) 91: 217-225.

LIESEGANG A, SASSI ML AND RISTELI J. 2003. Diurnal variation in concentrations of various markers of bone metabolism in growing female goats and sheep. Anim Scien 77: 197-203.

LILL CA, FLUEGEL AK AND SCHNEIDER E. 2002a. Effect of ovariectomy, malnutrition and glucocorticoid application on bone properties in sheep: a pilot study. Osteoporosis Int 13: 480-486.

LILL CA, GERLACH UV, ECKHARDT C, GOLDHAHN J AND SCHNEIDER E. 2002b. Bone changes due to glucocorticoid application in an ovariectomized animal model for fracture treatment in osteoporosis. Osteoporosis Int 13: 407-414.

LOMEO A AND BOLNER A. 2000. Stability of several biochemical markers of bone metabolism. Clin Chem 46: 1200-1202.

MACLEAY JM, OLSON JD, ENNS RM, LES CM, TOTH CA, WHEELER DL AND TURNER AS. 2004a. Dietaryinduced metabolic acidosis decreases bone mineral density in mature ovariectomized ewes. Calcif Tissue Int 75: 431437.

MACLEAY JM, OLSON JD AND TURNER AS. 2004b. Effect of dietary-induced metabolic acidosis and ovariectomy on bone mineral density and markers of bone turnover. J Bone Miner Metab 22: 561-568.

MASROUR RJ AND MAHJOUB S. 2012. Quantification and comparison of bone-specific alkaline phosphatase with two methods in normal and paget's specimens. Caspian J Intern Med 3: 478-483.

MILLAN JL. 2006. Alkaline Phosphatases: Structure, substrate specificity and functional relatedness to other members of a large superfamily of enzymes. Purinergic Signal 2: 335-341.

MOGHADDAM A, MULLER U, ROTH HJ, WENTZENSEN A, GRUTZNER PA AND ZIMMERMANN G. 2011. TRACP 5b and CTX as osteological markers of delayed fracture healing. Injury 42: 758-764.

NAFEI A, KABEL J, ODGAARD A, LINDE F AND HVID I. 2000. Properties of growing trabecular ovine bone. Part II: architectural and mechanical properties. J Bone Joint Surg (Br) 82: 921-927.

NEVE A, CORRADO A AND CANTATORE FP. 2013. Osteocalcin: Skeletal and extra-skeletal effects. J Cell Physiol 228: 1149-1153.

NEWMAN E, TURNER AS AND WARK JD. 1995. The potential of sheep for the study of osteopenia: current status and comparison with other animal models. Bone 16: 277-284.

NEWTON BI, COOPER RC, GILBERT JA, JOHNSON RB AND ZARDIACKAS LD. 2004. The ovariectomized sheep as a model for human bone loss. J Comp Pathol 130: 323-326.

NICODEMO ML, SCOTT D, BUCHAN W, DUNCAN AAND ROBINS SP. 1999. Effects of variations in live weight gain on bone growth and composition and on markers of bone turnover in lambs. Exp Physiol 84: 579-587.

O'LOUGHLIN PF, MORR S, BOGUNOVIC L, KIM AD, PARK B AND LANE JM. 2008. Selection and development of preclinical models in fracture-healing research. J Bone Joint Surg (Am) 90(1): 79-84.

PASKALEV M AND KRASTEV S. 2010. Alterations in serum tartrate-resistant acid phosphatase and C-terminal telopeptide of type I collagen in experimental canine osteotomies fixed using 2 different techniques. Turk J Vet Anim Sci 34: 227-233. 
PASTOUREAU P, MEUNIER PJ AND DELMAS PD. 1991. Serum osteocalcin (bone Gla-protein), an index of bone growth in lambs. Comparison with age-related histomorphometric changes. Bone 12: 143-149.

PEARCE AI, RICHARDS RG, MILZ S, SCHNEIDER E AND PEARCE SG. 2007. Animal models for implant biomaterial research in bone: a review. Eur Cell Mater 13: 1-10.

PRICE JS, JACKSON B, EASTELL R, WILSON AM, RUSSELL RG, LANYON LE AND GOODSHIP AE. 1995. The response of the skeleton to physical training: a biochemical study in horses. Bone 17: 221-227.

RAGGATT LJ AND PARTRIDGE NC. 2010. Cellular and molecular mechanisms of bone remodelling. J Biol Chem 285: 25103-25108.

RAVAGLIOLI A, KRAJEWSKI A, CELOTTI GC, PIANCASTELLI A, BACCHINI B, MONTANARI L, ZAMA G AND PIOMBI L. 1996. Mineral evolution of bone. Biomaterials 17: 617-622.

REICHERT JC, SAIFZADEH S, WULLSCHLEGER ME, EPARI DR, SCHUTZ MA, DUDA GN, SCHELL H, VAN GM, REDL H AND HUTMACHER DW. 2009. The challenge of establishing preclinical models for segmental bone defect research. Biomaterials 30: 2149-2163.

REINWALD S AND BURR DB. 2011. Other large animal models. In: Duque G and Watanabe K (Eds), Osteoporosis Research, London: Springer-Verlag, London, UK, p. 159174.

SCHMIDT J, WINKER H, SCHMIDT I, EKKERNKAMP A AND MERK H. 2008. Biochemical control of callus maturation: An experimental animal study. Z Orthop Unfall 146: 490-497.

SCHMIT JM, PONDENIS HC, BARGER AM, BORST LB, GARRETT LD, WYPIJ JM, NEUMANN ZL AND FAN TM. 2012. Cathepsin K expression and activity in canine osteosarcoma. J Vet Intern Med 26: 126-134.

SCOTT D, LOVERIDGE N, NICODEMO L, BUCHAN W, MILNE J, DUNCAN A, NICOL P AND ROBINS P. 1997. Effect of diets varying in nitrogen or phosphorus content on indicators of bone growth in lambs. Exp Physiol 82: 193-202.

SEEBECK P, BAIL HJ, EXNER C, SCHELL H, MICHEL R, AMTHAUER H, BRAGULLA H AND DUDA GN. 2005. Do serological tissue turnover markers represent callus formation during fracture healing? Bone 37: 669-677.

SEEMAN E. 2009. Bone modelling and remodelling. Crit Rev Eukaryot Gene Expr 19: 219-233.

SEIBEL MJ. 2002. Nutrition and molecular markers of bone remodelling. Curr Opin Clin Nutr Metab Care 5: 525-531.

SEIBEL MJ. 2005. Biochemical markers of bone turnover: Part I: Biochemistry and variability. Clin Biochem Rev 26: $97-122$

SEIBEL MJ. 2006. Clinical application of biochemical markers of bone turnover. Arq Bras Endocrinol Metabol 50: 603-620.
SEIBEL MJ, LANG M AND GEILENKEUSER WJ. 2001. Inter-laboratory variation of biochemical markers of bone turnover. Clin Chem 47: 1443-1450.

SEIBEL MJ, ROBINS SP AND BILEZIKIAN JP. 1992. Urinary pyridinium crosslinks of collagen: specific markers of bone resorption in metabolic bone disease. Trends Endocrinol Metab 3: 263-270.

SIGRIST IM, GERHARDT C, ALINI M, SCHNEIDER E, EGERMANN M. 2007. The long-term effects of ovariectomy on bone metabolism in sheep. J Bone Miner Metab 25: 28-35.

SMITH SY, VARELA A AND JOLETTE J. 2011. Nonhuman Primate Models of Osteoporosis. In: Duque G, Watanabe K (Eds), Osteoporosis Research, London: Springer-Verlag, London, UK, p. 135-158.

SOUBERBIELLE JC, CORMIER C AND KINDERMANS C. 1999. Bone markers in clinical practice. Curr Opin Rheumatol 11: 312-319.

SOUSA C, ABREU H, VIEGAS C, AZEVEDO J, REIS R, GOMES ME AND DIAS I. 2011. Serum total and bone alkaline phosphatase and tartrate-resistant acid phosphatase activities for the assessment of bone fracture healing in dogs. Arq Bras Med Vet Zootec 63: 1007-1011.

SOUSA CP, AZEVEDO JT, SILVA AM, VIEGAS CA, REIS RL, GOMES ME AND DIAS IR. 2014a. Serum total and bone alkaline phosphatase levels and their correlation with serum minerals over the lifespan of sheep. Acta Vet Hung 62: 205-214.

SOUSA CP, DE AZEVEDO JT, REIS RL, GOMES ME AND DIAS IR. 2014b. Short-term variability in biomarkers of bone metabolism in sheep. Lab Anim (NY) 43: 21-26.

SOUSA CP, DIAS IR, LOPEZ-PEÑA M, CAMASSA JA, LOURENÇO PJ, JUDAS FM, GOMES ME AND REIS RL. 2015. Bone turnover markers for early detection of fracture healing disturbances: A review of the scientific literature. An Acad Bras Cienc 87: 1049-1061.

TATARA MR. 2008. Neonatal programming of skeletal development in sheep is mediated by somatotrophic axis function. Exp Physiol 93: 763-772.

TAYLOR MS, KNOWLTON KF, MCGILLIARD ML, SWECKER WS, FERGUSON JD, WU Z AND HANIGAN MD. 2009. Dietary calcium has little effect on mineral balance and bone mineral metabolism through twenty weeks of lactation in Holstein cows. J Dairy Sci 92: 223-237.

TRALMAN G, ANDRIANOV V, AREND A, MANNIK P, KIBUR RT, NOUPUU K, UKSOV D AND AUNAPUU M. 2013. A novel combined method of osteosynthesis in treatment of tibial fractures: a comparative study on sheep with application of rod-through-plate fixator and bone plating. Anat Histol Embryol 42: 80-89.

TURNER AS. 2001. Animal models of osteoporosis - necessity and limitations. Eur Cell Mater 22: 66-81. 
TURNER AS. 2007a. Experiences with sheep as an animal model for shoulder surgery: strengths and shortcomings. J Shoulder Elbow Surg 16: S158-S163.

TURNER AS. 2007b. Seasonal changes in bone metabolism in sheep: Further characterization of an animal model for human osteoporosis. Vet J 174: 460-461.

TURNER AS, ALVIS M, MYERS W, STEVENS ML AND LUNDY MW. 1995. Changes in bone mineral density and bone-specific alkaline phosphatase in ovariectomized ewes. Bone. 17: 395S-402S.

VAN DER DONK S, BUMA P, ASPENBERG P AND SCHREURS BW. 2001. Similarity of bone ingrowth in rats and goats: a bone chamber study. Comp Med 51: 336340.

VASIKARAN S, COOPER C, EASTELL R, GRIESMACHER A, MORRIS HA, TRENTI T AND KANIS JA. 2011. International osteoporosis foundation and international federation of clinical chemistry and laboratory medicine position on bone marker standards in osteoporosis. Clin Chem Lab Med 49: 1271-1274.

VERNON KL, RIGGS L, COVERDALE J, BODINE AB AND GIBBONS J. 2010. The effects of forced exercise on collagen type II fragments, lysyl oxidase concentrations, and total protein concentrations in sera and synovial fluid of lambs. J Equine Vet Sci 30: 266-274.

WAN ZAHARI M, SCOTT D, LOVERIDGE N, BUCHAN W AND MILNE J. 1994. The effect of high phosphorus intake on calcium and phosphorus retention and bone turnover in growing lambs. Exp Physiol 79: 175-181.

WATTS NB. 1999. Clinical utility of biochemical markers of bone remodelling. Clin Chem 45: 1359-1368.

WHEATER G, ELSHAHALY M, TUCK SP, DATTA HK AND VAN LAAR JM. 2013. The clinical utility of bone marker measurements in osteoporosis. J Transl Med 11: 201.

WHYTE MP. 1994. Hypophosphatasia and the role of alkaline phosphatase in skeletal mineralization. Endocr Rev 15: 439-461.

WILKENS MR, MROCHEN N, BREVES G AND SCHRODER B. 2010. Effects of 1,25-dihydroxyvitamin D3 on calcium and phosphorus homeostasis in sheep fed diets either adequate or restricted in calcium content. Domest Anim Endocrinol 38: 190-199.

WINDHAGEN H, WITTE F, HURSCHLER C, MACIEJEWSKI O, LINNENBERG D AND THOREY F. 2002. Bone turnover during distraction osteogenesis in an experimental sheep model. Arch Orthop Trauma Surg 122: $279-282$.

\section{SUPPLEMENTARY MATERIAL}

Table SIV - Characteristics of the animal and veterinary science studies that reported the use of BTMs in different types of research. 
